\title{
Chemical-Free Recovery of Crude Protein from Livestock Manure Digestate Solid by Thermal Hydrolysis
}

Ken Tasaki ( $\sim$ kt@bkt21.com )

Tomorrow Water https://orcid.org/0000-0001-5647-3470

\section{Research Article}

Keywords: antioxidant, cow manure, protein hydrolysate, thermal hydrolysis

Posted Date: May 3rd, 2021

DOI: https://doi.org/10.21203/rs.3.rs-441997/v1

License: (c) (1) This work is licensed under a Creative Commons Attribution 4.0 International License.

Read Full License

Version of Record: A version of this preprint was published at Bioresources and Bioprocessing on July 12th, 2021. See the published version at https://doi.org/10.1186/s40643-021-00406-1. 


\section{Abstract}

Protein is becoming an increasingly important resource for a variety of commercial applications. Yet, a large volume of protein is being wasted. Notably, livestock manure solids have a significant content of protein which is not only underutilized, but prone to runoff and eventual breakdown to reactive nitrogen compounds, contributing to eutrophication. It would be desirable to remove protein before it causes environmental hazards and then convert it to value-added commercial applications. We have developed a novel thermal hydrolysis process (THP) to extract crude protein from livestock manure solid, or manure digestate solid (MDS) in particular, without the use of any chemical. We demonstrate the versatility of our new process to control the molecular weight (MW) distribution of the extracted protein hydrolysate $(\mathrm{PH})$. The antioxidant activity of the crude protein hydrolysate $(\mathrm{CPH})$ has been examined through Oxygen Radical Absorbance Capacity Assay. The results have shown that our $\mathrm{CPH}$ had its antioxidant capacity against the peroxyl radical similar to that of vitamin $\mathrm{E}$ and exhibited almost 7 times as strong inhibition against the hydroxyl radical as vitamin E. We also evaluated the nutritional value of our PH by analyzing its amino acid composition and the MW distribution through amino acid analysis, SDS-PAGE, and MALDITOF mass spectroscopy. The characterizations have revealed that the PH recovered from MDS had 2.5 times as much essential amino acids as soybean meal on dry matter basis, with the MW distribution ranging from over a hundred $\mathrm{Da}$ to $100 \mathrm{KDa}$. Finally, the protein powder was prepared from the extracted $\mathrm{CPH}$ solution and its composition was analyzed.

\section{Introduction}

Livestock manure solids contain a considerable amount of crude protein, from $12 \mathrm{wt} . \%$ to $48 \mathrm{wt} . \%$, depending on the animal and the growth period, according to the report by Pacific Northwest National Laboratories (PNNL) (Chen et al. 2003). There is a substantially large volume of crude protein in livestock manure that could be potentially recovered (see Table S1) (Livestock Wastes Subcommittee 1993; U.S. Department of Agriculture, 2020). Currently, such crude protein is being wasted. Protein in manure tends to stay in the soil longer when manure is sprayed on croplands since it is not available to plants immediately as nutrient; hence, it can be subject to runoff to waterways or leaching to groundwater before the complete breakdown of protein, if not properly treated. Crude protein belongs to what is called biologically nondegradable organic nitrogen compounds (BNON) which are difficult to treat by conventional biological treatment processes (Kim et al. 2000). It would be beneficial if crude protein is recovered from manure before it causes environmental problems such as eutrophication and then the recovered crude protein is converted to value-added products from environmental and economical points of view.

Protein has been attracting increasing attentions in biotechnology (Pasupuleti 2000), nutrition science (Pasupuleti et al. 2010; McCalla et al 2010), and materials science (Dhillon 2016; Silva et al. 2014; Hu et al. 2012). In this report, we refer all the organic nitrogen compounds included in manure solids to as crude protein and designate true protein composed of amino acids (AAs) alone as protein. One important application of protein in manure solids, rarely explored, may be using its hydrolysate as antioxidants. 
Recently, a number of studies have shown that peptides with low molecular weight (MW) fractions have exhibited the antioxidant activity (Wu et al 2003). Antioxidant peptides extracted from various food sources are attracting increasing interest because they provide a natural and safe alternative to many synthetic antioxidants (Hook et al. 2001). Compared to synthetic antioxidants, these peptides usually have relatively low MWs, stable structures and high activities, and are easily absorbed without hazardous immunoreactions (Qian et al. 2008). The range of MW for peptides having antioxidant activity has been reported to be $<3,000$ Da by one report (Kim et al. 2019) and $400 \sim 2,000$ Da by another (Liu et al. 2016). Mostly, enzymatic process was used for extraction from various sources in the previous studies. However, enzymatic process can be costly at a commercial scale (Wu et al. 2003; Adhikari et al. 2019; Liu et al.; Feng et al.; Ye et al.; Kim et al.; Davalos et al.; Sila and Bougatef 2016; Wang et al. 2018; Yang et al. 2018; Zou et al.; 2016; Hook et al. 2001; Qian et al. 2008).

Vitamin E is a well-known antioxidant to alleviate the oxidative stress of animals. However, the price of vitamin E can be subject to the volatility and unexpected supply shortages. It would be desirable to have an alternative to vitamin E. The supply of livestock manure as the raw material is steady and uninterrupted, given the increasing global demand for meat.

A process of protein extraction from manure solid has been patented (Vanotti and Szogi 2019). The process uses a high concentration of alkali chemical $\sim 1 \mathrm{M}$. The use of chemical requires not only separation of the chemical from protein, but recycle or disposal of the chemical as well. We have developed a chemical-free recovery process, using thermal hydrolysis process (THP). THP has been applied to extraction of bioactive compounds from plants successfully (Nastića et al., 2018; Liang and Fan, 2013). Very few reports have been published on application of THP for protein recovery from manure solid in the literature.

For commercial application, making a powder out of the extracted protein is crucial, given the transportation of the final product to the market and the storage issue. Transportation of the protein solution can be costly, depending on the protein concentration.

We use the manure digestate solid (MDS) as the sample. It contains not only protein that was not digested by animal body, but also cellular protein inside microbes such as methanogens that are rich in protein. In order to recover the protein from such microbes, the microbe cells need to be ruptured for the recovery. Our objective in this study is to extract crude protein from MDS and hydrolyze it by THP and recover the hydrolysate by a shear wave-induced membrane ultrafiltration (SWIMU), using no chemical solvent, but only water. THP may be effective for extracting cellular protein inside microbes by breaking the cell membranes. Microbial cell disruption by THP has been reported (Baskar et al. 2019)).

We examined the crude protein hydrolysate $(\mathrm{CPH})$ recovered from MDS for the antioxidant activity, and the protein hydrolysate $(\mathrm{PH})$ for the AA composition and the MW distribution. We also prepared a powder of the $\mathrm{CPH}$ solution by removing water and analyzed the composition of the powder. Our goal, however, is by no means to replace vitamin $\mathrm{E}$, but rather to provide alternative antioxidant to livestock farmers. 


\section{Materials And Methods}

\section{Materials}

The MDS sample was collected from the solid separated by a screw separator from the digestate effluent of $A D$ using manure of Jersey cattle as the feed on a dairy farm in California Central Valley. The MDS sample had a 50\% water content after being left under the sun for several days. The MDS sample was used for THP without any pretreatment. Some of the samples were dried in an oven overnight to prepare dry samples for the composition analysis.

\section{Composition of Materials}

The composition of the MDS sample solid before and after THP was analyzed to determine the contents such as crude protein, hemicellulose, cellulose, lignin, phosphorous, potassium, and others. For the crude protein analysis, a combination of the flow injection analyzer by HACH (Hach Company, Ames, ISA) for the inorganic nitrogen $\left(\mathrm{NO}_{3}\right.$ and $\left.\mathrm{NH}_{4}\right)$ and the combustion system for the total nitrogen (TN) were used. The crude protein content was estimated by subtracting the inorganic nitrogens $\left(\mathrm{NH}_{4}, \mathrm{NO}_{3}\right.$, and $\left.\mathrm{NO}_{2}\right)$ from TN and multiplying the result by 6.25. The neutral detergent fiber (NDF), acid detergent (ADF), and acid detergent lignin (ADL) were measured by the Reflux method to analyze the lignocellulosic composition of the MDS sample (AAFCO, 2017). The nutrients such as phosphorous and potassium, alkali metals, and other metals were analyzed by Inductively Coupled Plasma Atomic Emission Spectrometry (ICP-AES). Each lignocellulose component was calculated by the following: hemicellulose = $N D F-A D F$, cellulose $=A D F-A D L$, and lignin $=A D L$.

See the Supplementary Material for the detailed instrumentation (Analytical and Assay Instrumentation, Supplementary Material) (AAFCO 2017).

\section{THP process}

We have developed a two-heating step process for extraction of crude protein from MDS by THP. The detailed description of the THP reaction vessel and the theoretical background are given in Supporting Material (Fig. S1, Supporting Material). At the first heating step, we denature protein by heating MDS at the temperature $T_{1}$ close to the denaturing temperature of the protein. At the second step at the temperature $T_{2}\left(>T_{1}\right)$ at which the solution becomes acidic, having a higher concentration of the hydronium ions, we perform hydrolysis of the extracted protein. Denaturing is essential to break down the protein to low-MW peptides by hydrolysis since the electrophile to break the peptide bonds cannot have sufficient access to the peptide bonds when the protein is folded. In addition, the water's other unique characteristics, that its density, dynamic viscosity, and surface tension all decrease significantly at high temperatures, promote the mass transfer of all the components in the solid matrices and increase the wettability of the protein molecule in the manure solid. We achieve the extraction/denaturing and hydrolysis of protein by the two-heating step process we have developed. As to the other nitrogen compounds, basically the same principle can be applied. 
The temperature and the reaction time can control the extraction yield and the degree of hydrolysis of the protein. By adjusting the temperatures, we can control how much crude protein can be extracted from manure solid and how low the MW of the hydrolysate is. In determining the heating temperatures for the 1st and 2nd steps for our THP, considerations were given to the denaturing temperature of protein for the 1 st step, while yielding as much low-MW fractions as possible for the 2 nd step. As to the denaturing temperature, some proteins are known to denature at $50^{\circ} \mathrm{C}$ (Olsson et al 2016), while many proteins denature irreversibly over $80^{\circ} \mathrm{C}$ (Cavagnero et al. 1998; Pothekin et al. 2000; McAfee et al. 1996; Pfeil et al. 1997; Pappenberger et al. 1997). It is also possible that protein in the manure solid may well be denatured already. Since it is not known whether or not the protein in the manure solid is denatured, it was decided that the $1 \mathrm{st}$ heating temperature $\left(T_{1}\right)$ was fixed at $100^{\circ} \mathrm{C}$. As to the 2 nd heating temperature $\left(T_{2}\right), 130^{\circ} \mathrm{C}$ and $160^{\circ} \mathrm{C}$ were chosen to examine the effect of $T_{2}$ on the degree of the protein hydrolysis. We chose two conditions for THP: $\mathrm{T}_{1}=100{ }^{\circ} \mathrm{C}$ for $1 \mathrm{hr}$. followed by $\mathrm{T}_{2}=130{ }^{\circ} \mathrm{C}$ for $1 \mathrm{hr}$. (to be referred to as THP I) and $T_{1}=100{ }^{\circ} \mathrm{C}$ for $1 \mathrm{hr}$. followed by $\mathrm{T}_{2}=160^{\circ} \mathrm{C}$ for $1 \mathrm{hr}$. (to be referred to as THP II). $60 \mathrm{~g}$ of MDS, $30 \mathrm{~g}$ of which was the dry matter, was mixed in $1 \mathrm{~L}$ of deionized water for THP without pretreatment. The $\mathrm{CPH}$ s under the two conditions, THP I and THP II, will be referred to as $\mathrm{CPH}$ I and $\mathrm{CPH}$ II, respectively. Likewise, PH I and PH II are the protein hydrolysate prepared under THP I and THP II, respectively.

\section{Protein filtration by ultrafiltration}

SWIMU generates a vortex flow, by rotating the membrane disk, effectively preventing membrane fouling. The membrane fouling resistance can be reduced by as much as an order of magnitude, relative to a conventional cross-flow filtration (Kim et al., 2015). The reaction solution after the THP process was first filtered by a $90 \mathrm{~mm}$ mesh screen, followed by SWIMU with a $150 \mathrm{KDa}$ membrane from which the permeate was recovered as the $\mathrm{CPH}$ sample which was used for the characterizations described in the following subsections. The detail of SWIMU is provided in Supplementary Material (SWIMU, Supplementary Material) (Kim et al. 2015). No separation of the PH from the rest of CPH were performed. Hence, the $\mathrm{CPH}$ sample was a mixture of $\mathrm{PH}$ and the non-protein nitrogen compounds.

\section{Sodium dodecyl sulfate polyacrylamide gel electrophoresis}

The MW distribution of the samples was determined by Sodium dodecyl sulfate polyacrylamide gel electrophoresis (SDS-PAGE). The samples were first diluted to a $2.5 \mathrm{mg} / \mathrm{mL}$ concentration in a sample buffer containing $2.3 \%$ sodium dodecyl sulfate (SDS), $10 \%$ glycerol, $50 \mathrm{mM}$ dithiothreitol, and $63 \mathrm{mM}$

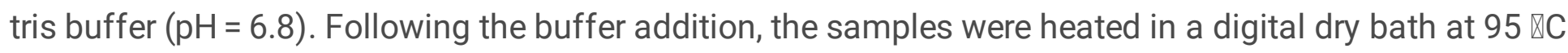
for $10 \mathrm{~min}$. SDS slab gel electrophoresis was carried out using a $16.5 \%$ acrylamide peptide slab gel. The slab gel was stopped once the bromophenol blue front had migrated to the end of the slab gel. Following the slab gel completion, the gel was stained with Coomassie blue dye, destained in $10 \%$ acetic acid until a clear background was obtained and dried between cellophane sheets.

\section{MALDI-TOF mass spectroscopy}


The matrix-assisted laser desorption ionization time-of-flight (MALDI-TOF) mass spectroscopy was performed to analyze the MW distribution of the samples by using a Bruker ultraflextreme MALDI-TOF mass spectrometer (Bruker, Billerica, USA) with a $2 \mathrm{kHz}$ SmartBeam laser for desorption and ionization of the samples. a-cyano-4-hydroxycinnamic acid was used as the matrix. The original sample was diluted to 5 picomoles for the measurements.

\section{Oxygen Radical Absorbance Capacity against the peroxyl and hydroxyl radicals}

For ORAC against the peroxyl radical, 2,2'-Azobis (2-amidino-propane) dihydrochloride (AAPH) was used as the source for the peroxyl radical, which was generated as a result of the spontaneous decomposition of AAPH at $37^{\circ} \mathrm{C}$. Fluorescein was used as the chosen target protein, whose loss of fluorescence was an indication of the extent of damage from its reaction with the peroxyl radical. The protective effect of the antioxidants was measured by assessing the longer fluorescence time/intensity area under the curve of the sample compared to the blank, in which no antioxidant compounds were present. The concentration of the protein hydrolysate extracted from the MDS sample was $10 \%$. The concentration of the protein hydrolysate was increased by circulating the concentrate from reverse osmosis filtration. Trolox, a watersoluble analog of vitamin E, was used as the calibration standard. On the other hand, the hydroxyl radical antioxidant capacity assay was performed by measuring the antioxidant capacity of the protein hydrolysate to protect fluorescein from damage by the hydroxyl radical which was generated from reactions between cobalt and hydrogen peroxide. The antioxidant capacity of the protein hydrolysate was measured by assessing the longer fluorescence time/intensity area under the curve of the protein hydrolysate compared to the blank, in which no sample was present. Trolox was used as the calibration standard.

All oxygen radical absorbance capacity (ORAC) assays were performed by Brunswick Laboratories (Southborough, MA).

\section{Amino acid analysis}

The AA composition of the protein hydrolysate powder was analyzed by Hitachi L-8800 AA analyzer (Tokyo, Japan). Ion-exchange chromatography (IEC) was used to separate each AA followed by a postcolumn ninhydrin reaction detection system. Each sample was thoroughly hydrolyzed prior to IEC. Their standard hydrolysis procedure employed $6 \mathrm{~N} \mathrm{HCl}$ for 24 hrs at $110 \bowtie \mathrm{C}$.

\section{Electron spin resonance spectroscopy analysis}

THP may have generated radicals in the $\mathrm{CPH}$ samples. To determine the existence of radical in the crude protein hydrolysate, electron spin resonance (ESR) spectroscopy was employed. The instrument was Bruker EMXPlus spectrometer (Bruker, Billerica, USA) operating at X-band frequency $(\sim 9.8 \mathrm{GHz})$ using a Bruker ER4119HS high sensitivity resonator (Bruker, Billerica, USA). Continuous wave electron spin resonance spectra were recorded at room temperature. The modulation amplitude was $1.0 \mathrm{G}$, with the modulation frequency at $100 \mathrm{kHz}$, the conversion time of $5 \mathrm{msec}$, and the time constant of $2.56 \mathrm{msec}$. This analysis can help interpret the results of the antioxidant activity assay. One possibility for the antioxidant activity of the MDS hydrolysate, if any, is radical disproportionation in which two radicals are 
combined to form a non-radical compound. The result from this analysis can either eliminate the possibility or confirm the possibility.

\section{DNA analysis}

Increasing antibiotic resistance gene in the environment is serious public concern. Some antibiotic resistance genes have been found in livestock manure (Wichmann et al. 2014). Since THP can rupture microbial cells in the MDS sample, it was possible that some genetic materials may stay in the reaction solution after THP. The analysis was performed for the $\mathrm{CPH}$ sample based on fluorescence quenching detection. Electropherogram was applied to quantify the genetic materials in the sample. The Maxwell DNA IQ kit (Promega, Madison, USA) was used for extraction of the sample, while the QuantiFiler Trio kit (Thermo Fisher Scientific, Waltham, USA) was utilized for the quantification of DNA. The concentration limit by these instruments was 1 ppm. The detailed DNA analysis is given in Supplementary Material (Analytical and Assay Instrumentation, Supplementary Material).

\section{Powder preparation}

The powder was prepared by removing water from the $\mathrm{CPH}$ II aqueous solution by a combination of reverse osmosis (RO) and a vacuum evaporation. The SWIMU permeate was further filtered by RO and circulated the concentrate from RO until the permeate stopped coming out of RO. The pressure applied to the RO membrane was $150 \mathrm{psi}$ and the recovery rate was $80 \%$. As a result, the concentration of the $\mathrm{CPH}$ II solution, or the SWIMU permeate, can be increased by five-fold by the RO process. The RO system was manufactured by Membrane Solution (Shanghai, China). The maximum flow rate was 150 gallons per day. The length and the diameter of the membrane element was 12 " and 2", respectively. The concentrate from RO was vacuum evaporated under $700 \mathrm{mmHg}$ at $40^{\circ} \mathrm{C}$ to further remove water. The slurry in the flask after the vacuum evaporation was removed and dried in an oven over night. The dried solid was ground by a pestle.

\section{Results And Discussion}

\section{Composition of Materials}

Table 1 summarizes the compositions of the original MDS sample and the leftover solid after THP on dry matter basis. The THP condition was THP II.

\section{Table 1}

Compositions of MDS Samples before and the Leftover Solid after THP under THP II (wt.\% ) ${ }^{\mathrm{a}}$. 


\begin{tabular}{|llllllll|}
\hline Solid Sample & Crude protein & P & K & Hemicellulose & Cellulose & Lignin & Others $^{\mathbf{b}}$ \\
\hline before THP & 37.2 & 2.1 & 1.5 & 9.3 & 18.2 & 30.2 & 1.5 \\
\hline after THPc & 14.8 & 3.5 & 0.1 & 14.8 & 29.0 & 48.3 & 2.5 \\
\hline a Dry matter basis. & & & & & & \\
\hline & bAlkali metals such as Na, Ca, and Mg. \\
\hline
\end{tabular}

The crude protein content in the original MDS sample was higher than the value for cow manure solid previously reported by the PNNL group, $18.1 \mathrm{wt}$ \% (Chen et al. 2003). The manure solid composition can vary, depending not only on cow species, but also on the feed, the season, and the climate. In addition, our MDS which likely contained cellular protein from microbes after anaerobic digestion. Still, the pure protein content was $30.7 \%$ based on AAA. The difference between the crude protein and the pure protein is due to the non-protein nitrogen compounds such as urea, humic acid, amino sugar, and others which are known to exist in manure solids (He et al. 2014; Khandelwal and Gaur 1980). The most significant compositional difference before and after THP in the solid is that more than a half of the crude protein was dissolved from the original MDS sample under THP II. On the other hand, phosphorous mostly stayed in the leftover solid, while potassium dissolved in the solution after THP. As to the lignocellulosic compositions of MDS before THP, similar values have been reported (Tsapekos 2017; Zhong et al. 2016). After THP, the content of each lignocellulosic component actually increased in the leftover solid almost proportionally from that in the original MDS sample, as a result of the dissolution of crude protein. It suggests that they didn't dissolve much into the solution during THP. A study on hot-water extraction from spruce wood has reported that delignification started at $170^{\circ} \mathrm{C}$, dissolving mostly hemicellulose from the wood (Krogell et al. 2013). Since our THP temperature was $160^{\circ} \mathrm{C}$, hemicellulose may not have dissolved much in the solution. Still, a direct comparison may be difficult, given that the lignocellulose in the MDS sample were partially digested during anaerobic digestion. The composition analysis of the protein powder, described later, will reveal more about the lignocellulose dissolution later. At least, any traceable amount of sugars such as glucose or xylan as a result of hemicellulose hydrolysis was not detected in the $\mathrm{CPH}$ sample.

Table 1 only lists the major components. Not included are other components such as alkali metals such as $\mathrm{Ca}, \mathrm{Na}$, and $\mathrm{Mg}$ in a few percentages and traces of other metals such as $\mathrm{Fe}, \mathrm{Mn}$, and $\mathrm{Zn}$ in a ppm range. The compositions of heavy metals such as $\mathrm{Cd}$ and As in the leftover solid were less than $10 \mathrm{ppm}$.

\section{Protein recovery yield}

We focused on the pure protein for the recovery yield $(R Y)$, defined by the following equation: 
$R Y=100 \times \frac{\left[W_{\text {hydrolysate }}\right]}{\left[W_{\text {protein }}\right]}$

where $\left[W_{\text {hydrolysate }}\right]$ and $\left[W_{\text {protein }}\right]$ refer to the weight of the $\mathrm{PH}$ in the reaction solution after THP and the weight of the pure protein in the original sample prior to THP, respectively. Table 2 summarizes the recovery yields under THP I and THP II.

\section{Table 2}

Recovery yields under THP I and THP II.

\begin{tabular}{|llll|}
\hline Condition & $W_{\text {protein }} \mathrm{g}^{\mathrm{a}}$ & $W_{\text {hydrolysate }} \mathrm{g}^{\mathrm{a}}$ & $R Y, \%$ \\
\hline THP I & 9.21 & 3.21 & 34.85 \\
\hline THP II & 9.21 & 5.55 & 60.26 \\
\hline${ }^{\mathrm{a}} \mathrm{dry}$ matter basis. & \\
\hline${ }^{\mathrm{b}} \mathrm{T}_{1}=100^{\circ} \mathrm{C}$ for $1 \mathrm{hr}$. and $\mathrm{T}_{2}=130^{\circ} \mathrm{C}$ for $1 \mathrm{hr}$. \\
\hline${ }^{\mathrm{c}} \mathrm{T}_{1}=100^{\circ} \mathrm{C}$ for $1 \mathrm{hr}$. and $\mathrm{T}_{2}=160^{\circ} \mathrm{C}$ for $1 \mathrm{hr}$. \\
\hline
\end{tabular}

The numbers listed in Table 2 were determined by AAA. $W_{\text {protein }}$ was the weight of protein in the MDS sample of $60 \mathrm{~g}$ used for THP, of which $30 \mathrm{~g}$ was the dry matter. $W_{\text {hydrolysate }}$ was the weight of PH in $1 \mathrm{~L}$ of reaction solution after THP. The higher second heating temperature significantly increased the recovery yield. We attribute this to the increased thermal energy at the 2 nd heating step that facilitated the protein extraction. From Table 1, the dissolved crude protein was about $6.73 \mathrm{~g}$ out of $30 \mathrm{~g}$ of the dry MDS under THP II. With the dissolved protein of $5.55 \mathrm{~g}$, the dissolved non-protein was about $1.18 \mathrm{~g}$. One of the nonprotein nitrogen compounds, urea decomposes to $\mathrm{NH}_{3}$ and biurea at $130{ }^{\circ} \mathrm{C}$ (Tischer et al. 2019). The decomposition temperature of biurea is $230 \sim 260^{\circ} \mathrm{C}$ (Russell and Strachan 1978). Thermogravimetric data have shown humic acid started decomposing around $200^{\circ} \mathrm{C}$ (Antunes et al. 2007), while thermal decomposition studies on amino sugars are scarce. They were all likely dissolved in the solution after THP. Vanotti et al did not include he recovery yield in their patent (Vanotti and Szogi 2019).

\section{MW Distributions}

Figure 1 displays the SDS-PAGE band images for the PHs prepared under THP I and THP II. CPH I exhibited the continuous bands with some dark distinctive bands around $30 \mathrm{~K} \mathrm{Da}, 40 \mathrm{~K} \mathrm{Da}, 50 \mathrm{~K} \mathrm{Da}$, and 
a few lines up to $95 \mathrm{~K} \mathrm{Da}$, demonstrating a wide range of high $\mathrm{MW}$ fractions. On the other hand, $\mathrm{CPH}$ II showed very few lines, indicating almost no fractions within the range analyzed. The bands shown in Fig. 1 are primarily due to protein, not non-protein nitrogen compounds whose MW are mostly below 1 $\mathrm{KDa}$.

Figure (a) and (b) exhibit the MALDI-TOF mass spectra for CPH I and CPH II, respectively. The reference peptide, shown at $1046.79 \mathrm{~m} / \mathrm{z}$, was added to the sample prior to MALDI-TOF-mass spectroscopy measurements for comparison between the two samples. Though several peaks were seen in both charts, based on the peak height of the reference peptide, the concentration of low MW fractions in $\mathrm{CPH}$ II was much higher than that in $\mathrm{CPH}$ I below $1,000 \mathrm{~m} / \mathrm{z}$ within which most peaks appear. Peptides in this region were low-MW peptides such as oligopeptides or free AAs. The concentration of the hydolysates in Fig. $<$ link rid="fig2">2</link> (b) can be calculated from the peak positions and their intensities of each signal relative to the reference. It was about $2.9 \mathrm{~g} / \mathrm{L}$ which is close to the value of $W_{\text {hydrolysate }}$ in Table 2 . We believe that the difference in the MW distribution between THP I and THP II is due to $\mathrm{T}_{2}$ for THP II (> $\mathrm{T}_{2}$ for THP I) which provided a higher hydronium concentration, resulting in more rigorous hydrolysis, breaking protein into smaller peptides. $\mathrm{pH}$ is 5.9 and 5.7 at $130^{\circ} \mathrm{C}$ and $160^{\circ} \mathrm{C}$, respectively (Plaza and Turner 2015). Based on the difference in $\mathrm{pH}$, THP II had about $60 \%$ more hydronium concentration than THP I.

Based on the results from MALDI-TOF mass spectroscopy and SDS-PAGE, we conclude that CPH II had much more low MW fractions than $\mathrm{CPH}$ I which had its fractions more distributed over higher $\mathrm{MW}$ ranges, as is demonstrated by SDS-PAGE. Accordingly, we will focus on CPH II in the following characterizations since earlier studies reported low MW peptides exhibited antioxidant activities.

\section{ORAC against the peroxyl and hydroxyl radicals}

Figure 3 (a) and (b) plot the inhibition of the peroxyl radical attack against fluorescein protein by Trolox and $\mathrm{CPH} I \mathrm{I}$, respectively, as a function of logarithm of the sample concentration, $C$. The two curves exhibit similar profiles to one another, though Trolox reached $100 \%$ inhibition at a somewhat lower concentration than $\mathrm{CPH}$ II. Still, the value of $\mathrm{IC}_{50}$ for $\mathrm{CPH} \mathrm{II,} 7.67 \mathrm{mg} / \mathrm{L}$, was very close to that of Trolox, $8.08 \mathrm{mg} / \mathrm{L}$, demonstrating that the antioxidant activity of $\mathrm{CPH}$ II was as strong as Trolox against the peroxyl radicals. $I_{50}$ refers to the concentration of the sample at which the inhibition is $50 \%$.

Figure 4 (a) and (b) show the inhibition of the hydroxyl radical attack against fluorescein protein by Trolox and $\mathrm{CPH}$ II, respectively, as a function of logarithm of $C$. Here, we observed a significant difference between the two samples: the inhibition by $\mathrm{CPH}$ II reached $100 \%$ at a much lower concentration than Trolox did, with $\mathrm{IC}_{50}$ of $107.6 \mathrm{mg} / \mathrm{L}$, less than $1 / 7$ of that of Trolox, $741 \mathrm{mg} / \mathrm{L}$. The result suggests that the antioxidant activity of $\mathrm{CPH}$ II was more than 7 times as strong as Trolox. The observation that $\mathrm{CPH}$ II exhibited antioxidant activities is consistent with the previous studies on peptides (Wu et al. 2003; Adhikari et al. 2019; Liu et al.; Feng et al.; Ye et al.; Kim et al.; Davalos et al.; Sila and Bougatef 2016; Wang et al. 2018; Yang et al. 2018; Zou et al.; 2016; Hook et al. 2001; Qian et al. 2008). A theoretical study on the antioxidant activity of peptides has been published (Leung et al. 2018). 
It should be noted that the sample $\mathrm{CPH}$ II includes not only $\mathrm{PH}$, but the other nitrogen compounds such as humic acid, amino sugar, and biurea extracted from the original MDS sample. Both humic acid and amino sugar have the hydroxyl groups which can involve in the mechanisms associated with inhibition of radicals through the electron or the hydrogen atom transfer. In fact, some studies have reported the antioxidant activities of humic acid and some amino sugars (Kammaz et al. 2016; Kitts et al. 2012; Banaszkiewicz 2011). There are also a number of studies showing strong antioxidant activities of peptides, as was mentioned earlier. These non-protein nitrogen compounds were about $17 \%$ of the total dissolved crude protein, as was described above. Since we didn't remove these nitrogen compounds from the $\mathrm{CPH}$ II sample, their contributions to the inhibition of the radicals cannot be ignored. Our data only demonstrates that the extracted compounds from the MDS sample and recovered by UF with $150 \mathrm{KDa}$ inhibited both peroxyl and hydroxyl radicals, to the extent that the ability to inhibit the former radical is comparable to that of Trolox and the ability in inhibit the latter is 10 times stronger than Trolox.

\section{AA Composition}

Figure 5 compares the AA composition of PH II (PH under THP II) and that of soybean (the white bars) on dry matter basis (Banaszkiewicz 2011). The cysteine content of PH II was low due to the oxidation of the thiol during THP. According to Fig. 5, CPH II had 2.5 times as much essential AAs as those of soybean meal on dry matter basis. Further, it had 2.3 times as much nitrogen source as that of soybean meal on dry matter basis. The low MW distribution of PH II may help its digestion by animals. The use of PHs has been growing in animal nutrition as an important nutrient (McCalla 2010). Still, feed tests such as digestibility test need to be conducted for further confirmation for $\mathrm{PH}$ II to be as an effective feed additive. The difference in the content of the essential AAs between PH II and soybean meal is mainly due to the fact that the protein content in PH II was $75.17 \%$ on dry matter basis, as shown below, while the protein content in soybean meal is $47.5 \%$.

\section{CPH Powder}

Table 3 summarizes the composition of the powder prepared from the CPH II sample.

\section{Table 3}

Composition of $\mathrm{CPH}$ II Powder (\%). ${ }^{\mathrm{a}}$

\begin{tabular}{|lllllllllll|}
\hline $\begin{array}{l}\text { Crude } \\
\text { protein }\end{array}$ & $\mathbf{P}$ & $\mathrm{K}$ & Hemicellulose & Cellulose & Lignin & $\mathbf{C d}$ & $\mathbf{P b}$ & As & Others $^{\mathrm{b}}$ \\
\hline 90.96 & 1.97 & 4.41 & 0.32 & 0.04 & 0.01 & $0.1^{\mathrm{C}}$ & $10.3^{\mathrm{C}}$ & $1.5^{\mathrm{C}}$ & 1.99 \\
\hline
\end{tabular}

a Based on dry matter.

bAlkali metals such as $\mathrm{Na}$ and $\mathrm{Mg}$, sugars such as glucose and fructose.

'In ppm. 
The components listed in Table 3 were the total dissolved solids (TDS) recovered from the permeate of SWIMU and rejected by the RO membrane. The powder showed a high content of crude protein, of which $75.17 \%$ was protein based on AAA and $15.78 \%$ was the other nitrogen organic compounds by subtracting the amount of the protein from the amount of the crude protein. The potassium content was relatively high, given more potassium being dissolved than phosphorous by THP. Very low components of the lignocellulosic components were found in the powder. Accordingly, it is very unlikely that the antioxidant activities are due to the lignocellulosic components. The others include alkali metals such as sodium and magnesium. The concentrations of heavy metals such as arsenic, cadmium, and lead were less than $10 \mathrm{ppm}$.

It is known that manure can contain prion (Tamgüney et al. 2009). It has been reported, however, that the conversion of a normal prion to an aberrant scrapie isoform triggering transmissible spongiform encephalopathies involves the formation of a new intermolecular disulfide bond (Welker et al. 2001). Our AAA indicates that no cystine residue was found in PH II. Cystine is the AA having the disulfide bond. In fact, THP oxidizes the disulfide bond, releasing the $\mathrm{H}_{2} \mathrm{~S}$ gas. The destruction of the disulfide bonds in the misfolded prion results in a loss of the prion's tertiary structure, hence removing its ability to transmit the misfolded shape onto a normal form of prion.

\section{DNA analysis}

Prior to DNA analysis for $\mathrm{CPH}$ II, a number of known DNA samples were tested for calibration of the instrument, showing the expected cycle threshold (CT) values. For CPH II, however, no fluorescence was observed above the threshold over PCR amplification; hence, no CT was obtained to determine the concentration of genetic materials in our sample. The observation demonstrated that the binding of a fluorescent detector molecule to DNA molecules did not occur in our sample and therefore, no genetic materials were detected by the analysis, at least those higher than $1 \mathrm{ppm}$. Accordingly, no chart is presented. This result strongly suggests that no genetic materials higher than $1 \mathrm{ppm}$ were extracted by THP from the MDS sample. A number of studies have reported that the application of THP significantly reduced the abundance of antibiotic resistant genes and mobile genetic elements in sewage sludge (Tong et al. 2017; Pei et al. 2016; Ma et al. 2011). It has been suggested that during THP, the high temperature and pressure sterilized the sludge floc and destroyed cell walls, which made the degradable components readily released (Tong et al. 2017; Pei et al. 2016; Ma et al. 2011; Donoso-Bravo et al. 2011). It has been also reported that DNA was susceptible to thermal hydrolytic destruction (Tong et al. 2017).

\section{ESR spectroscopy}

The ESR spectroscopy chart for CPH II exhibited only noise signals. Fig. S2 shows the ESR spectra (Fig. S2, Supplementary Material). The sample was measured at various power levels, starting with the lowest power level, in an attempt to locate an EPR signal without causing saturation effects. No signal characteristic to a single electron spin, or radical, was observed in the range studied. The result indicates that radicals were not present in the $\mathrm{CPH}$ II sample, at least no more than $1 \mathrm{ppm}$. However, it is possible that radicals were produced during THP, but the radicals may have been short-lived through 
disproportionation. ESR spectroscopy was performed a day after the sample preparation. On the other hand, the ORAC assay was performed several weeks after the sample preparation. Based on this observation, it seems unlikely that $\mathrm{CPH}$ II inhibited either the peroxyl or the hydroxyl radicals through radical disproportionation. On the other hand, it is likely that other mechanisms such as electron transfer, hydrogen atom transfer, and proton loss may be at work (Pham-Huy et al. 2008). However, discussion on the mechanism is beyond the scope of this work. We will report the radical scavenging mechanism by $\mathrm{CPH}$ II in a separate study.

\section{Conclusion}

We have successfully extracted crude protein from MDS and hydrolyzed by our two-step THP process under two conditions and recovered by the SWIMU filtration system. This process can be used to remove crude protein from manure before reaching to the environment and convert it to value-added products. Once crude protein can be removed from manure solids, there will be less BNON left in the solids, making easier for biological waste treatment of manure solid or MDS.

We also have demonstrated that the $\mathrm{CPH}$ characteristics can be controlled by adjusting the THP condition. For example, we found that $\mathrm{CPH}$ I treated by $\mathrm{THP}$ at $\mathrm{T}_{2}=130^{\circ} \mathrm{C}$ had high $\mathrm{MW}$ fractions, higher than a few thousand $\mathrm{Da}$, while $\mathrm{CPH}$ II treated at $\mathrm{T}_{2}=160^{\circ} \mathrm{C}$ had lower $\mathrm{MW}$ fractions, lower than 2,000 Da, based on SDS-PAGE and MALDI-TOF mass spectroscopy. The ORAC assays demonstrated that CPH II had strong antioxidant activities against both peroxyl and hydroxyl radicals, achieving a nearly $100 \%$ inhibition of the radicals. Especially, the results suggested that the antioxidant activity of CPH II was nearly 7 times as strong as Trolox. ESR spectroscopy detected no radical for $\mathrm{CPH}$ II, removing a possibility of the reduction of the peroxyl or the hydroxyl radicals by radical disproportionation. Still, the antioxidant assays conducted in this study should be regarded as preliminary. More extensive study is warranted on the antioxidant activity of the CPH extracted by THP. It is also of importance to note that the antioxidant activity tests reported here were in-vitro tests. In-vivo and toxicology tests will be required before petitioning to FDA for approval as animal dietary supplement, among other tests. As to the nutritional aspect of our $\mathrm{CPH}$, we have found that the AA composition of $\mathrm{PH}$ II had 2.5 times as much essential AAs as those of soybean meal and 2.3 times as much nitrogen source as that of soybean meal on dry matter basis. The nutritional value of the $\mathrm{CPH}$ will require a validation through animal test.

\section{List Of Abbreviations}

AAIAmino Acid

AAAAmino Acid Analysis

AAPH $囚 2,2$ '-Azobis (2-amidino-propane) dihydrochloride

ADAnaerobic Digestion

Page 13/23 
BNON Biologically Nondegradable Organic Nitrogen Compounds

CPHCrude Protein Hydrolysate

CTCycle Threshold

ESRElectron Spin Resonance

MDSManure Digestate Solid

MWMolecular Weight

ORACOxygen Radical Absorbance Capacity

PHProtein Hydrolysis

PNNLPacific Northwest National Laboratories

ROReverse Osmosis

RYRecovery Yield

SSSuspended Solids

SWIMUShear Wave-Induced Membrane Ultrafiltration

TDSTotal Dissolved Solids

THPThermal Hydrolysis Process

THP ITHP condition with $\mathrm{T}_{1}=100^{\circ} \mathrm{C}$ for $1 \mathrm{hr}$. and $\mathrm{T}_{2}=130^{\circ} \mathrm{C}$ for $1 \mathrm{hr}$.

THP II THP condition with $\mathrm{T}_{1}=100^{\circ} \mathrm{C}$ for $1 \mathrm{hr}$. and $\mathrm{T}_{2}=160^{\circ} \mathrm{C}$ for $1 \mathrm{hr}$.

\section{Declarations}

Ethics approval and consent to participate not applicable.

Consent for publication: not applicable.

Competing interests: The authors declare that they have no competing interests

Funding: No funding has been received for this work.

Conflicts of interest/Competing interests: No conflicts of interest/competing interest exist. 
Availability of data and material: The supplementary information is available.

Author's contribution: KT conceived an idea for the protein recovery process, using THP and UF, made the experimental design, conducted the experiments, prepared the samples, sent out the samples to thirdparty labs for the analyses, and prepared the manuscript.

Competing interest: The author declares that he has no known competing financial interests or personal relationships that could have appeared to influence the work reported in this paper.

\section{Acknowledgements}

The author acknowledges Mr. Harrison of Figure8Environmental for providing a financial support and the MDS sample. He also thanks valuable discussions with Prof. Stein at University of Illinois at UrbanaChampaign on animal nutrition and indispensable help from Mr. Kaneoka and Mr. Lin for conducting the SWIMU filtration system and Dr. Rhu for his valuable comments on THP.

\section{References}

AAFCO's Laboratory methods and services committee fiber best practices working group. Critical factors in determining fiber in feeds and forages; Champaign, IL, January, 2017.

Adhikari B, Dhungana SK, Ali MW, Adhikari A, Kim ID, Shin DH (2019) Antioxidant activities, polyphenol, flavonoid, and amino acid contents in peanut shell. $J$ the Saudi Soc Agricultural Sciences 18: 437-442.

Antunes M, Fernandes AN, Crespo JS, Giovanela M (2007) Thermal degradation of humic acids from aquatic environments. Anais do $9^{\circ}$ Congresso Brasileiro de Polímeros, Corpus ID: 229321856.

Banaszkiewicz T (2011) Nutritional value of soybean meal, In: El-Shemy H (ed) Soybean and Nutrition, IntechOpen DOI: 10.5772/23306.

Baskar G, Kalavathy G, Aiswarya R, Selvakumari IA (2019) Advances in bio-oil extraction from nonedible oil seeds and algal biomass. In: Azad K (ed) Advances in eco-fuels for a sustainable environment, woodhead publishing series in energy, Elsevier, Amsterdam, 187-210.

Cavagnero S, Debe DA, Zhou ZH, Adams MWW, Chan SI (1998) Kinetic role of electrostatic interactions in the unfolding of hyperthermophilic and mesophilic rubredoxins. Biochemistry 37: 3369-3376.

Chen S, Liao W, Liu C, Wen Z, Kincaid RL, Harrison JH, Elliott DC, Brown MD, Solana AE, Stevens DJ (2003) Value-added chemicals from animal manure. PNNL-14495, Pacific Northwest National Laboratory, Richmond, Washington, December.

Davalos A, Miguel M, Bartolome B, Lopez-Fandino R (2004) Antioxidant activity of peptides derived from egg white proteins by enzymatic hydrolysis. J Food Protection 67: 1939-1944. 
Dhillon G S (ed) (2016) Protein byproducts, Academic Press: London, 2016.

Donoso-Bravo A, Pérez-Elvira S, Aymerich E, Fdz-Polanco F (2011) Assessment of the influence of thermal pre-treatment time on the macromolecular composition and anaerobic biodegradability of sewage sludge. Bioresour Technol 102: 660-666.

Feng P, Ding H, Lin H, Chen W (2017) The antioxidant protein database. Scientific Reports 7, 7449, DOI:10.1038/s41598-017-08115-6.

He ZQ, Senwo ZN, Zou HX, Tazisong IA, Martens DA (2014) Amino compounds in poultry litter, litteramended pasture soils and grass shoots. Pedosphere 24: 178-185.

Hook VYH, Burton D, Yasothornsrikul S, Hastings RH, Deftos LJ (2001) Proteolysis of ProPTHrP (1-141) by prohormone thiol protease at multibasic residues generates PTHrP-related peptides: implications for PTHrP peptide production in lung cancer cells. Biochemical and Biophysical Research Communications 285: 932-938.

Hu X, Cebe P, Weiss AS, Omenetto F, Kaplan DL (2012) Protein-based composite materials. Materials Today 15: 208-215; DOI: 10.1016/S1369-7021(12)70091-3.

Kanmaz KS, Balta Z, Demirçivi P, Üzer A, Hızal J, Apak R (2016) Determination of total antioxidant capacity of humic acids using CUPRAC, Folin-Ciocalteu, noble metal nanoparticle- and solid-liquid extraction-based methods. Talanta 153: 120-129.

Khandelwal KC, Gaur AC (1980) Degradation of humic acids, extracted from manure and soil by some Streptomycetes and Fungi. Zentralbl Bakteriol Naturwiss 135: 119-22; DOI: 10.1 016/s03236056(80)80014-0.

Kim K, Jung J, Kwon JH, Yang JW (2015) Dynamic microfiltration with a perforated disk for effective harvesting of microalgae. J Membr Sci 475: 252-258.

Kim JM, Liceaga AM, Yoon KY (2019) Purification and identification of an antioxidant peptide from perilla seed (Perilla frutescens) meal protein hydrolysate. Food Sci Nutr 7, 1645-1655; DOI: 10.1002/fsn3.998.

Kim R, Zinbo, M, Adams J A, Young WC (2000) Nonbiodegradable organic compounds found in automotive spraybooth scrubber water. Water Environment Research 72: 405-412.

Kitts DD, Chen XM, Hao JH (2012) Demonstration of antioxidant and anti-inflammatory bioactivities from sugar-amino acid maillard reaction products. J Agric Food Chem 60: 6718-6727.

Krogell J, Korotkova E, Eränen K, Pranovich A, Salmi T, Murzin D, Willför S (2013) Intensification of hemicellulose hot-water extraction from spruce wood in a batch extractor - effects of wood particle size. Bioresour Technol 143: 212-220, DOI:10.1016/j.biortech.2013.05.110. 
Li N, Liu H, Xue Y, Wang H, Dai X (2017) Partition and fate analysis of fluoroquinolones in sewage sludge during anaerobic digestion with thermal hydrolysis pretreatment. Sci Total Environ 581-582: 715-721.

Liang X, Fan Q (2013) Application of sub-critical water extraction in pharmaceutical industry. Journal of Materials Science and Chemical Engineering 1: 1-6. http://dx.doi.org/10.4236/msce.2013.15001.

Liu R, Xing L, Fu Q, Zhou GH, Zhang WG (2016) A review of antioxidant peptides derived from meat muscle and by-products. Antioxidants 5: 32. DOI:10.3390/antiox5030032.

Livestock Wastes Subcommittee (1993) Livestock Waste Facilities Handbook, $3^{\text {rd }}$ Ed., Midwest Plan Service, lowa State University, Ames, p2.1, ISBN 0-89373-089-0.

Lu J, Watson J, Zeng J, Li H, Zhu Z, Wang M, Liu Z (2018). Biocrude production and heavy metal migration during hydrothermal liquefaction of swine manure. Process Safety and Environmental Protection 115: 108-115.

Leung R, Venus C, Zeng T, Tsopmo A (2018) Structure-function relationships of hydroxyl radical scavenging and chromium-VI reducing cysteine-tripeptides derived from rye secalin. Food Chem 254: 165-169.

Ma Y, Wilson C, Novak JT, Riffat R, Aynur S, Murthy S, Pruden A (2011) Effect of various sludge digestion conditions on sulfonamide, macrolide, and tetracycline resistance genes and class I integrons. Environ Sci Technol 45: 7855-7861.

McAfee JG, Edmondson SP, Zegar I, Shriver JW (1996) Equilibrium DNA binding of Sac7d protein from the hyperthermophile Sulfolobus acidocaldarius: fuorescence and circular dichroism studies. Biochemistry 35: 4034-4045.

McCalla J, Waugh T, Lohry E (2010) Protein hydrolysates/peptides in animal nutrition. In: Pasupuleti VK, Demain AL (eds) Protein hydrolysates in biotechnology, Springer, Dordrecht, London, New York, 179-190.

Nastića N, Švarc-Gajića J, Delerue-Matosb C, Barroso MF, Soares C, Manuela MM, Morais S, Mašković P, Gaurina Srček VG, Slivac I, Radošević K, Radojković M (2018) Subcritical water extraction as an environmentally-friendly technique to recover bioactive compounds from traditional serbian medicinal plants. industrial crops and products. 111: 579-589.

Olsson C, Jansson H, Swenson J (2016) The Role of trehalose for the stabilization of proteins. J Phys Chem B 120: 4723-4731.

Pappenberger G, Schurig H, Jaenicke, R (1997) Disruption of an ionic network leads to accelerated thermal denaturation of d-glyceraldehyde-3-phosphate dehydrogenase from the hyperthermophilic bacterium Thermotoga maritima. J Mol Biol 274: 676-683. 
Pasupuleti V K, Demain A L (eds) (2010) Protein hydrolysates in biotechnology. Springer, Dordrecht, Heidelberg, London, New York.

Pasupuleti VK, Homes C, Demain AL (2010) Applications of protein hydrolysates in biotechnology. In: Pasupuleti VK, Demain AD (eds) Protein hydrolysates in biotechnology. Springer: Dordrecht, London, New York, pp 1-10.

Pei J, Yao H, Wang H, Ren J, Yu X (2016) Comparison of ozone and thermal hydrolysis combined with anaerobic digestion for municipal and pharmaceutical waste sludge with tetracycline resistance genes. Water Res 99: 122-128.

Pham-Huy LA, He H, Pham-Huy C (2008) Free radicals, antioxidants in disease and health. Int J Biomed Sci 4: 89-96.

Pfeil W, Gesierich U, Kleemann GR, Sterner R (1997) Ferredoxin from the hyperthermophile Thermotoga maritima is stable beyond the boiling point of water. J Mol Biol 272: 591-596.

Plaza M, Turner C (2017) Pressurized hot water extraction of bioactives. Trends in Anal Chem 71: 39-54.

Pothekin SA, Ogasahara K, Yutani K (2000) Transition state of heat denaturation of methionine aminopeptidase from a hyperthermophile. J Therm Anal Calorim 62: 111-122.

Qian ZJ, Jung WK, Byun HG, Kim SK (2008) Protective effect of an antioxidative peptide purified from gastrointestinal digests of oyster crassostrea gigas against free radical induced DNA damage. Bioresource Technology 99: 3365-3371.

Russell PR, Strachan AN (1978) The thermal decomposition of biurea. J Chem Soc Perkin Trans 2: 323326.

Sila A, Bougatef A (2016) Antioxidant peptides from marine by-products: isolation, identification and application in food systems. A review. J Functional Foods 21: 10-26.

Silva N H C S, Vilela C, Marrucho IM, Freire CSR, Neto CPAJD (2014) Protein-based materials: from sources to innovative sustainable materials for biomedical applications. J Mater Chem B 2: 3715-3740.

Tamgüney G, Miller, MW, Wolfe, LL, Sirochman TM, Glidden, DV, Palmer C, Lemus A, DeArmond, SJ, Prusiner SB (2009) Asymmptomatic deer excrete infectious prions in feces. Nature 24: 529-532.

Tischer S, Börnhorst M, Amsler J, Schoch G, Deutschmann, O (2019) Thermodynamics and reaction mechanism of urea decomposition. Phys Chem Chem Phys DOI: 10.1039/C9CP01529A.

Tsapekos P (2017) Enhancing biogas production from recalcitrant lignocellulosic residue. Ph.D. Thesis, Technical University of Denmark, DTU Environment, February. 
Tong J, Lu XT, Zhang JY, Sui Q, Wang R, Chen M, Wei Y (2017) Occurrence of antibiotic resistance genes and mobile genetic elements in enterococci and genomic DNA during anaerobic digestion of pharmaceutical waste sludge with different pretreatments. Bioresour Technol 235: 316-324.

U.S. Department of Agriculture (2020) Livestock and poultry: World markets and trade. Foreign Agricultural Service, July 10.

Vanotti M, Szogi A (2019) Extraction of amino acids and phosphorus from biological materials. U.S. Patent Application, 20190071370 , March 7.

Wang J, Liao W, Nimalaratne1 C, Chakrabarti S, Wu J (2018) Purification and characterization of antioxidant peptides from cooked eggs using a dynamic in vitro gastrointestinal model in vascular smooth muscle A7r5 cells. npj Science of Food 2: 7. doi:10.1038/s41538-018-0015-7.

Welker E, Wedemeyer WJ, Scheraga HA (2001) A role for intermolecular disulfide bonds in prion diseases? Proceedings of the National Academy of Sciences, 98: 4334-4336, DOI: 10.1073/pnas.071066598.

Wichmann F, Udikovic-Kolic N, Andrew S, Handelsman J (2014) Diverse antibiotic resistance genes in dairy cow manure. mBio 5(2): e01017-13; DOI:10.1128/ mBio.01017-13.

Wu HC, Shiau CY, Chen HM, Chiou TK (2003) Antioxidant activities of carnosine, anserine, some free amino acids and their combination. J Food Drug Analysis 11:148-153.

Yang J, Hu L, Cai T, Chen Q, Ma Q, Yang J, Hong, CMC (2018) Purification and identification of two novel antioxidant peptides from perilla (Perilla frutescens $\mathrm{L}$. Britton) seed protein hydrolysates. PLoS ONE 13(7): e0200021, https://doi.org/ 10.1371/journal.pone.0200021.

Ye N, Hu P, Xu S, Chen M, Wang S, Hong J, Chen T, Cai T (2018) Preparation and characterization of antioxidant peptides from carrot seed protein. J Food Quality Article ID 8579094, https://doi.org/10.1155/2018/8579094.

Zhang X, Li R (2018) Variation of antibiotics in sludge pretreatment and anaerobic digestion processes: degradation and solid-liquid distribution. Bioresour Technol 255: 266-272. https://doi.org/10.1016/j.biortech.2018.01.100.

Zhong Y, Liu Z, Isaguire C, Liu Y, Liao W (2016) Fungal fermentation on anaerobic digestate for lipidbased biofuel production. Biotechnol Biofuels 9: 253; DOI 10.1186/s13068-016-0654-3.

Zou TB, He TP, Li HB, Tang HW, Xia EQ (2016) The structure-activity relationship of the antioxidant peptides from natural proteins. Molecules 21: 72. DOI:10.3390/molecules21010072.

\section{Figures}




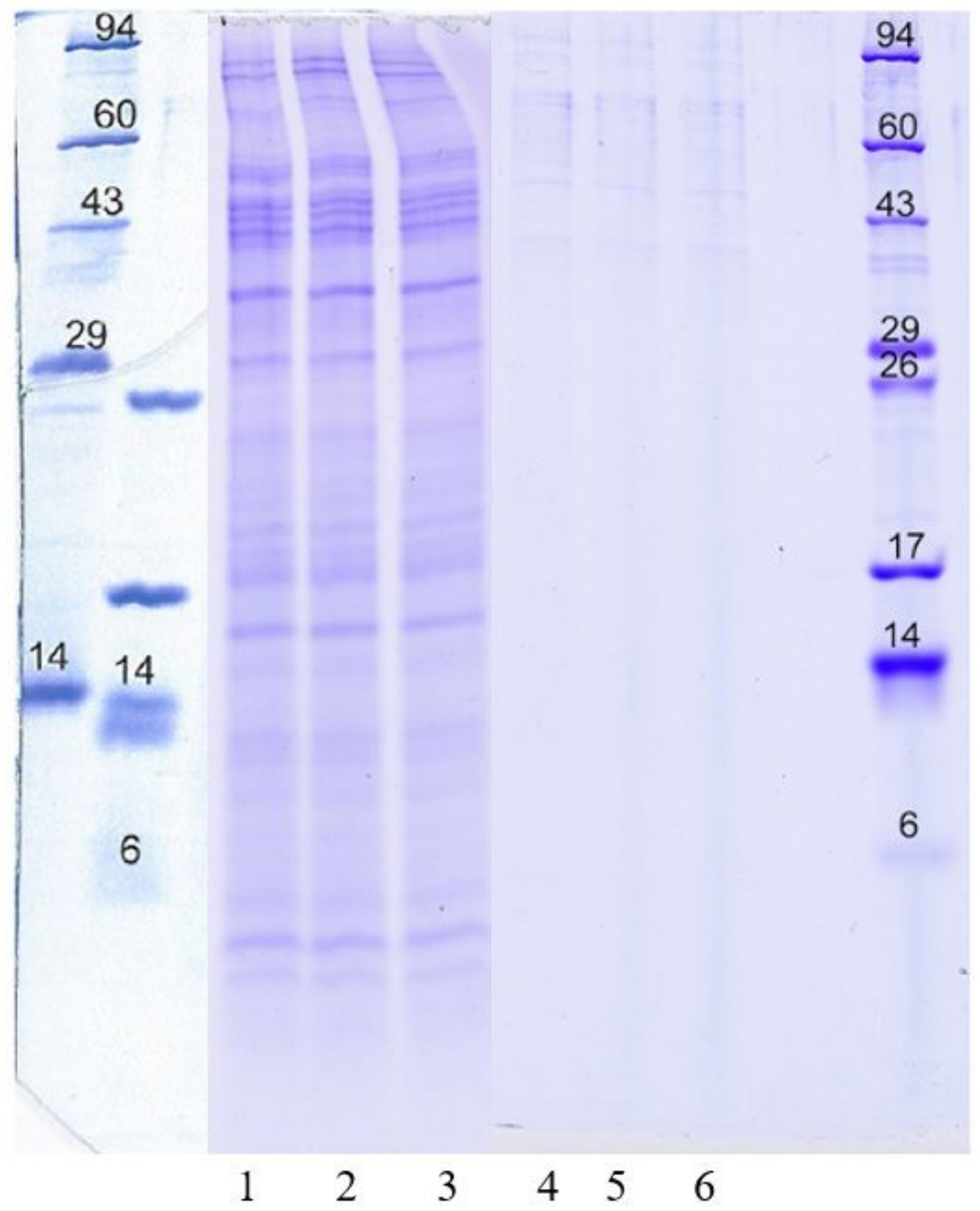

Figure 1

SDS-PAGE images of the PHs extracted from MDS: 1 3-PH I and 4 6-PH II. The measurements were performed triplicate. The numbers on both sides are the MW markers in KDa for which the following proteins were used as the standards: phosphorylase A $(94,000)$, catalase $(60,000)$, actin $(43,000)$, carbonic anhydrase $(29,000)$, myoglobin $(17,000)$, lysozyme $(14,000)$, aprotonin $(6,500)$, insulin chain b $(3,496)$. 

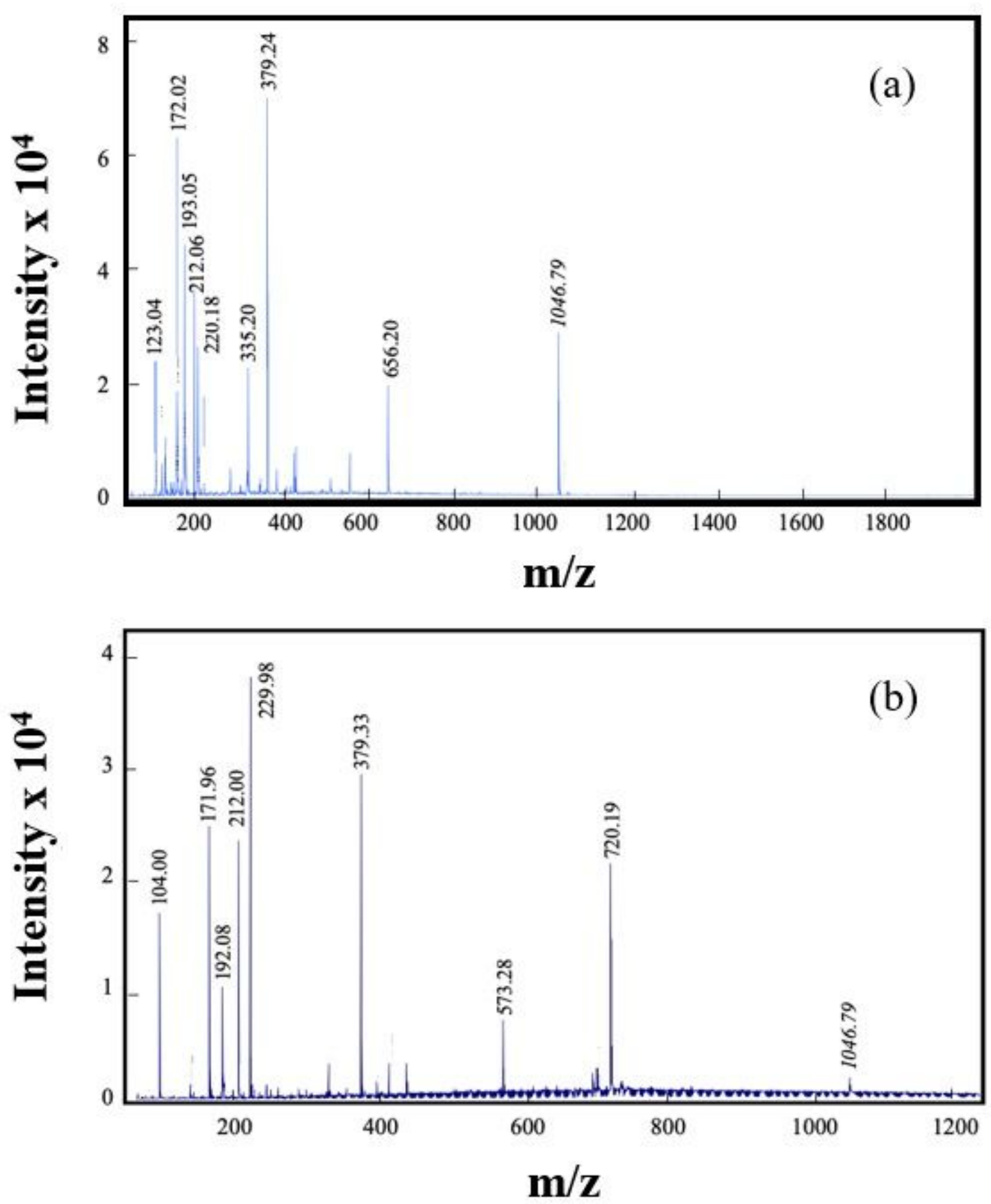

Figure 2

MALDI-TOF-mass spectra of (a) CPH I and (b) CPH II. A signal for a peptide with a known MW is included as a reference at $1046.79 \mathrm{~m} / \mathrm{z}$. 

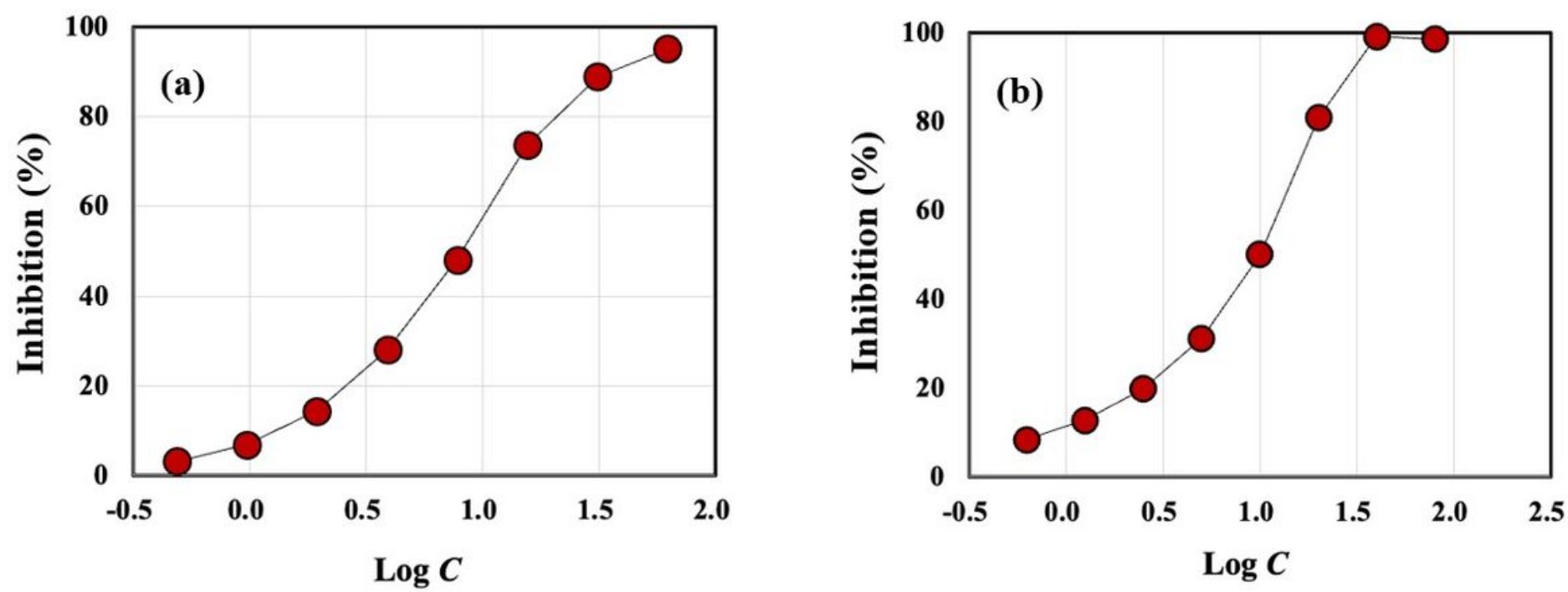

Figure 3

The inhibitions of the peroxyl radical by (a) Trolox and (b) $\mathrm{CPH}$ II in percentage as a function of logarithm of the $\mathrm{CPH}$ II concentration, $\mathrm{C}$ in $\mathrm{mg} / \mathrm{L}$.
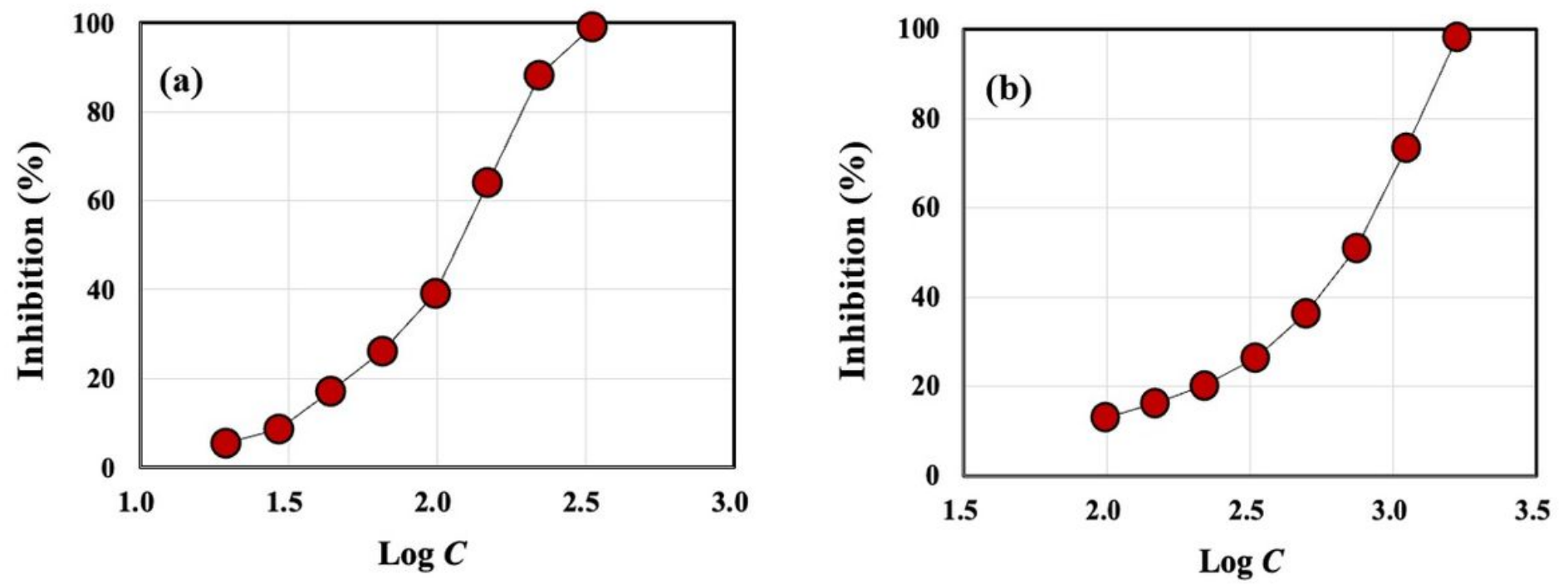

Figure 4

The inhibitions of the hydroxyl radical by (a) Trolox and (b) CPH II in percentage as a function of logarithm of the $\mathrm{CPH}$ II concentration, $\mathrm{C}$ in $\mathrm{mg} / \mathrm{L}$. 


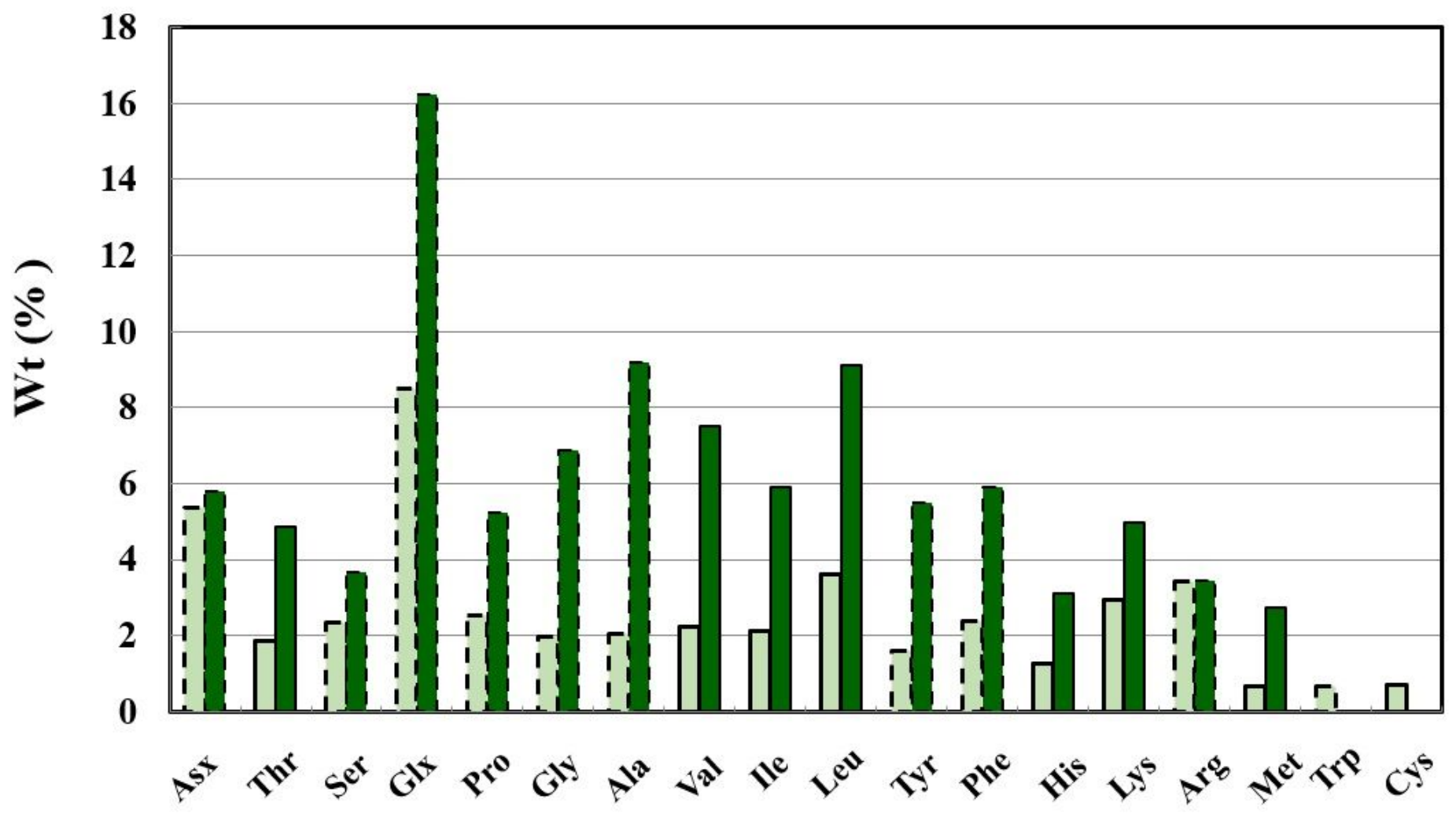

Figure 5

AA compositions of $\mathrm{PH} I \mathrm{l}$, shown by the dark green bars. The ordinate represents the wt $\%$ on dry matter basis, while the abscissa refers to the AA residues. The light green bars represent the AA composition of soybean meal. The bars with the broken line refer to unessential AAs, while those with the solid line are the essential AAs for hog and poultry. Asx: asparagine and aspartate; Glx: glutamine and glutamic acid.

\section{Supplementary Files}

This is a list of supplementary files associated with this preprint. Click to download.

- GraphicAbstract.jpg

- SupportingInformation.docx 